\title{
DOES PROFICIENCY LEVEL AFFECT LEARNERS' LEXICAL ACCESS IN L1 AND L2?
}

\author{
Muzakki Bashori* \\ Vocational High School of Wisudha Karya Kudus, Kudus City, Central Java 59319, Indonesia
}

A RTICLE INFO

Keywords:

Lexical access

Proficiency level

Article History:

Received: $12 / 10 / 2020$

Accepted: 19/05/2021

Available Online:

$31 / 05 / 2021$

\begin{abstract}
A B S T R A C T
Proficiency level is one important factor that contributes to learners' language performance. Learners with higher proficiency levels tend to perform lexical access better and faster than those with lower proficiency. This study aims to investigate whether proficiency level affects lexical access in L1 and L2. The research involved seven Indonesian university students of master's and doctoral degree programs at a university in the Netherlands who possess different proficiency levels. Two scrambled texts in the participants' L1 and L2 were employed to test the participants. Meanwhile, the paired-samples t-test and correlation analysis were used to report the experiment. The results revealed an insignificant difference and a negative correlation between proficiency level and the number of errors and reading time. However, on average, the more proficient learners outperformed the less proficient, thus indicating that they may possess more complex lexical access in L1 and L2. Further studies are needed to provide other useful insights on this topic.
\end{abstract}

2442-305X / ( 2021 The Author, this is open access article under the (CC-BY-NC) license (https://creativecommons.org/licenses/by-nc/4.0/), DOI: 10.19105/ojbs.v15i1.3877

\footnotetext{
$\overline{\text { * Corresponding Author: }}$

Email address: muzakkibashori90@gmail.com (M. Bashori)
}

\section{A. Introduction}

Language processing is considered a complex phenomenon in the human mind as it involves many interacting factors to be taken into account. The complexity increases when it comes to multilingual speakers who can speak multiple languages for communication. There is a particular path for multilingual speakers to access information from the languages they use. Notably, when provided with scrambled words both in their first and second language (L1 and L2), multilingual speakers are still able to notice and re-order the words correctly. It is therefore, interesting to examine the way their brain activates lexicons as well as the possible contributing factors.

The model proposed by Kroll and Dijkstra, ${ }^{1}$ namely Bilingual Interactive Activation (BIA), and the construct of

1 J. F. Kroll and A. Dijkstra, "The Bilingual Lexicon," in Handbook of Applied Linguistics, by R. Kaplan (Oxford: Oxford University Press, 2002), 301-21. 
Dynamic Systems Theory (DST) strengthened by De Bot, Lowie and Verspoor consider how multilingual speakers access L1 and L2 information stored in their own lexicons. ${ }^{2}$ This language phenomenon occurs due to various mental lexicons in the learners' given L1 and L2 words, which also depend on how each learner acquires the words. ${ }^{3}$ Hence, this paper aims to investigate whether (1) the participants' lexical access towards $L 1$ differs from that of $\mathrm{L} 2$ when reading scrambled texts in L1 and L2 under a measured time, and whether (2) proficiency level affects access of lexical items in L1 and L2.

\section{The BIA Model}

The BIA model encompasses four levels (feature level, letter level, word level, and language node level). Each level represents different stages that connect the visual input received by multilingual speakers. The last level, language node level, determines whether the individual succeeds in understanding the input being processed; otherwise, the input will be inhibited between the letter and the word level. This is known as the facilitating and inhibiting processes which occur during activation.

The BIA model is an extended version of the Interactive Activation (IA) model proposed by McClelland and

\footnotetext{
2 Kees De Bot, Wander Lowie, and Marjolyn Verspoor, Second Language Acquisition: An Advanced Resource Book (Routledge: Psychology Press, 2005).

${ }^{3}$ David Singleton, Exploring the Second Language Mental Lexicon (Cambridge: Cambridge University Press, 1999).
}

Rumelhart. ${ }^{4}$ According to this model, proficiency level contributes to the multilingual speaker's degree of lexical access to L1 and L2, as stated by Kroll and Dijkstra in De Bot, Lowie, and Verspoor that:

"The BIA model accounts for asymmetries observed in unbalanced bilinguals (stronger effects from L1 on L2 than vice versa) by assuming that, relative to $L 1$ words, the subjective frequency of $L 2$ words is lower for participants with lower L2 proficiency. This is implemented in terms of the model's resting level activations, which are generally lower for words in L2 than L1. As a consequence, L2 words, on the whole, become activated more slowly and to a lesser extent than L1 words." 5

According to Grosjean, L2 proficiency level influences lexical selection, along with language intermixing, task demands, and instruction. ${ }^{6}$ Moreover, Lengyel and Navracsics stated that learners with intermediate and good language proficiency have only some grammatical difficulties (e.g., congruency agreement and copula). ${ }^{7}$

\footnotetext{
${ }^{4}$ James L. McClelland and David E. Rumelhart, "An Interactive Activation Model of Context Effects in Letter Perception: I. An Account of Basic Findings," Psychological Review 88, no. 5 (1981): 375-407, https://doi.org/10.1037/0033-295X.88.5.375.

5 Bot, Lowie, and Verspoor, Second Language Acquisition, 159.

6 François Grosjean, "Studying Bilinguals: Methodological and Conceptual Issues," Bilingualism: Language and Cognition 1, no. 2 (1998): 131-49, https://doi.org/10.1017/S136672899800025X.

7 Zsolt Lengyel and Judit Navracsics, Second Language Lexical Processes, Second Language Lexical Processes (Clevedon: Multilingual Matters, 2007),

https://www.degruyter.com/document/doi/10.21832/ 9781853599682/html.
} 
Based on various experiments related to lexical access of multilingual speakers, De Bot, Lowie, and Verspoor agreed that proficiency level plays a significant role and directly affects the response time. ${ }^{8}$ Other elements, such as the semantic characteristics of a word and the degree of similarity of words in different languages, may also produce similar effects.

In relation to the Dynamic Systems Theory (DST), as explained by De Bot, Lowie, and Verspoor, the BIA model is in line with the notion that lexicon is constantly changing, with numerous interrelated factors which interact and influence each other over time. ${ }^{9}$ Hence, the level of activation for each lexical item is believed to be able to change continuously. Furthermore, Weinreich argued that as proficiency level develops, the type of organization (coordinate; a separate concept for each language, compound; one concept for different languages, and subordinate; one concept with indirect access of L2 via L1) can dynamically change. ${ }^{10}$

This dynamic model of the multilingual mental lexicon reveals that when a person is less proficient, they tend to possess subordinate organization, but as their proficiency increases, they may develop compound organization at later stages. Through this, proficient speakers are expected to have stronger lexical

\footnotetext{
8 Bot, Lowie, and Verspoor, Second Language Acquisition.

${ }^{9}$ Bot, Lowie, and Verspoor.

${ }^{10}$ Uriel Weinreich, Languages in Contact: Findings and Problems (Berlin: Walter de Gruyter, 2010).
}

access and would only face a few difficulties in re-ordering the words when reading scrambled texts in L1 and $\mathrm{L} 2$. Meanwhile, those at a low proficiency level will likely have more things to go through and consume more time.

One of the findings from a study by Persici et al. showed that bilingual proficiency influences responses to words that are similar in form but not meaning. ${ }^{11}$ Zolkapli and Salehuddin found that English language proficiency impacts how participants activate words from their mental lexicon. ${ }^{12}$ Additionally, Dixon and Rothkopf suggested that recency of exposure may promote: "...[w]ord "frequency" effects in reading and in learning from written material". ${ }^{13}$ However, relatively little is known about the use of scrambled text in investigating how proficiency level affects lexical access in L1 and L2 by Indonesian learners of English.

Therefore, the present study scrutinizes learners with different proficiency levels when reading two scrambled texts, one in English and the

\footnotetext{
11 Valentina Persici et al., "Lexical Access and Competition in Bilingual Children: The Role of Proficiency and the Lexical Similarity of the Two Languages," Journal of Experimental Child Psychology $179 \quad$ (2019): $103-25$, https://doi.org/10.1016/j.jecp.2018.10.002.

12 Rasyiqah Batrisya Md Zolkapli and Khazriyati Salehuddin, "Lexical Access Patterns of Second Language Speakers of English," Gema Online Journal of Language Studies 19, no. 4 (2019): 4865, https://doi.org/10.17576/gema-2019-1904-03.

13 Peter Dixon and Ernst Z. Rothkopf, "Word Repetition, Lexical Access, and the Process of Searching Words and Sentences," Journal of Verbal Learning and Verbal Behavior 18, no. 5 (1979): 629-44, https://doi.org/10.1016/S00225371(79)90354-2.
} 
other in Indonesian. Observing learners' errors (e.g., missing words) and their reading time might also provide useful insights into how they activate and access their lexical knowledge.

\section{B. Method}

\section{Participants}

The participants comprised seven individuals (four women, three men) who were Indonesian students of master's and doctoral degree programs at a university in the Netherlands. All participants were at different proficiency levels, as proven by their IELTS and TOEFL scores. It should also be noted that the participants were exposed to English on a daily basis since the language is widely used in the Netherlands. The participants' ages ranged from 23 to 38 . The Indonesian language was considered to be the participants' L1, although there was a possibility that they might be exposed to local languages first. The participants' L2 was English.

\section{Materials}

Two scrambled texts in L1 (Indonesian) and L2 (English) were used to test how the participants access their lexical items. The English text was originally taken from one of the author's files which had won a short-story competition in 2010. It was manually scrambled by keeping the first and last letters of the words in their original position. The text was then translated into Indonesian and followed the same scrambling procedure. The number of words for each text was sufficiently similar
(90 words for the L2 text and 85 words for the L1 text). Additionally, the numbers of verbs, nouns, adjectives, and adverbs between both texts were also quite equal. The time taken by the participants to read the text was subsequently recorded.

\section{Procedures}

The data was collected through six steps: determining the topic and research questions, reviewing related literature, interviewing and testing the subjects of study, reporting the results, and concluding the discussion. A reading test was employed to seek the correlation between the proficiency level and lexical access in L1 and L2. The data was then analyzed using the paired-samples t-test because two types of measurements were used to compare the means of all participants. The correlation analysis was also conducted to test the similarity among the variables.

\section{Results}

The seven participants were initially interviewed to obtain some basic information, especially on their English proficiency test scores. After, the participants collectively read two scrambled texts in L1 and L2 but in separate rooms to ensure that they did not hear what the others were reading. The time to read each scrambled text was recorded. The numbers of errors (missing words or MW) in L1 and L2 scrambled texts and the measured time and the IELTS score of each participant are provided in Table 1. below. 
Table 1.

The Participants' Data on the Proficiency Level, the Numbers of Errors (Missing Words), and the Measured Time

\begin{tabular}{llllll}
\hline Test Participant & $\begin{array}{l}\text { Proficiency Level } \\
\text { (IELTS/equivalent) }\end{array}$ & \multicolumn{2}{l}{ Errors (MW) } & \multicolumn{2}{l}{ Time (seconds) } \\
\cline { 3 - 6 } & & L1 text & L2 text & L1 Text & L2 Text \\
\hline P1 & 6.5 & 1 & - & $90 \mathrm{sec}$ & $82 \mathrm{sec}$ \\
P2 & 6.5 & - & 2 & $46 \mathrm{sec}$ & $62 \mathrm{sec}$ \\
P3 & 7.5 & - & - & $43 \mathrm{sec}$ & $40 \mathrm{sec}$ \\
P4 & 6 & 1 & 1 & $68 \mathrm{sec}$ & $56 \mathrm{sec}$ \\
P5 & 7 & - & 2 & $37 \mathrm{sec}$ & $39 \mathrm{sec}$ \\
P6 & 6.5 & 2 & 4 & $48 \mathrm{sec}$ & $52 \mathrm{sec}$ \\
P7 & 7 & 1 & 4 & $52 \mathrm{sec}$ & $57 \mathrm{sec}$ \\
\hline
\end{tabular}

On average, the number of errors (missing words) made by the participants consecutively in the L1 scrambled text was less than those in the L2 scrambled text $\quad(M=0.71, \quad S E=0.286 ; \quad M=1.86$, $\mathrm{SE}=0.634)$. There was an insignificant difference between the numbers of errors (missing words) in the L1 and L2 scrambled texts $(\mathrm{t}(6)=-2.066 ; p=0.084)$.

In terms of reading time, on average, the time needed by the participants consecutively when reading the L1 scrambled text was shorter than the L2 scrambled text $(M=54.86$, $\mathrm{SE}=6.902 ; \quad \mathrm{M}=55.43, \quad \mathrm{SE}=5.503)$. The difference between the reading time in the L1 and L2 scrambled texts was also not significant $(\mathrm{t}(6)=-0.163 ; p=0.876)$.

Meanwhile, the correlation analysis explains the association amongst proficiency level, the numbers of errors (missing words), and the reading time on the L1 and L2 scrambled texts. The results showed that:

1. There was a negative relationship between proficiency level and numbers of errors (missing words) in reading the L1 and L2 scrambled texts, $r=-0.484$ (L1 scrambled text); $p=0.271$ (twotailed); $r=-0.058$ (L2 scrambled text); $p=0.901 \quad$ (two-tailed). $p>0.05$ implies that the correlation is not significant.

2. There was a moderately strong negative relationship between the level of proficiency and time needed by the participants in reading $\mathrm{L} 1$ and $\mathrm{L} 2$ scrambled texts, $\quad \mathrm{r}=-0.538 \quad$ (L1 scrambled text); $p=0.212$ (two-tailed); $r=-0.543$ (L2 scrambled text); $p=0.208$ (two-tailed). $\quad p>0.05$ implies that the correlation is not significant. 

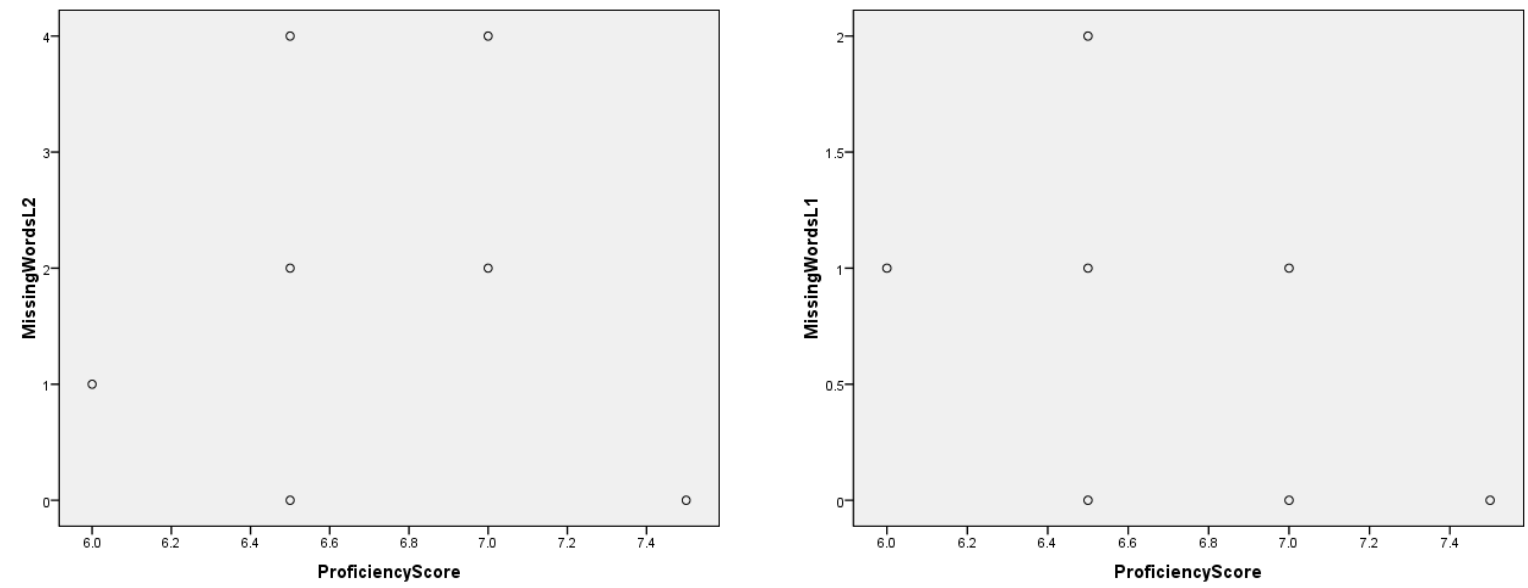

Fig. 1. Two scatter plots of Proficiency Level and Errors (Missing Words) when Reading the L1 and L2 Scrambled Texts
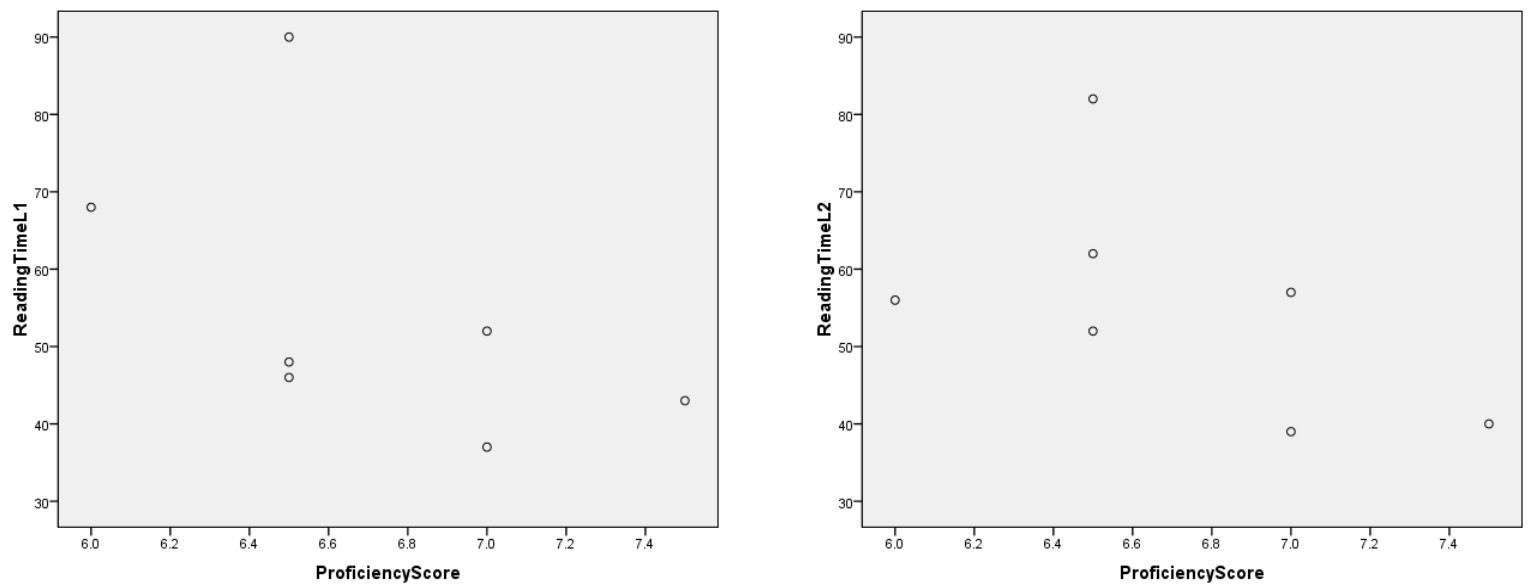

Fig. 2. The two scatter plots of Proficiency Level and Time when Reading the L1 and L2 Scrambled Texts

The figures above show the dispersion of data by seven participants with various proficiency scores. In the first two scatter plots, it can be compared between the numbers of errors made by the participants in L1 and L2 scrambled texts. Moreover, the latter two scatter plots show the difference between the reading time needed by the participants when they were asked to read L1 and L2 scrambled texts. In addition, two-line charts are presented below to give a clear idea about the correlation among the proficiency level, the numbers of errors, and the reading time. 


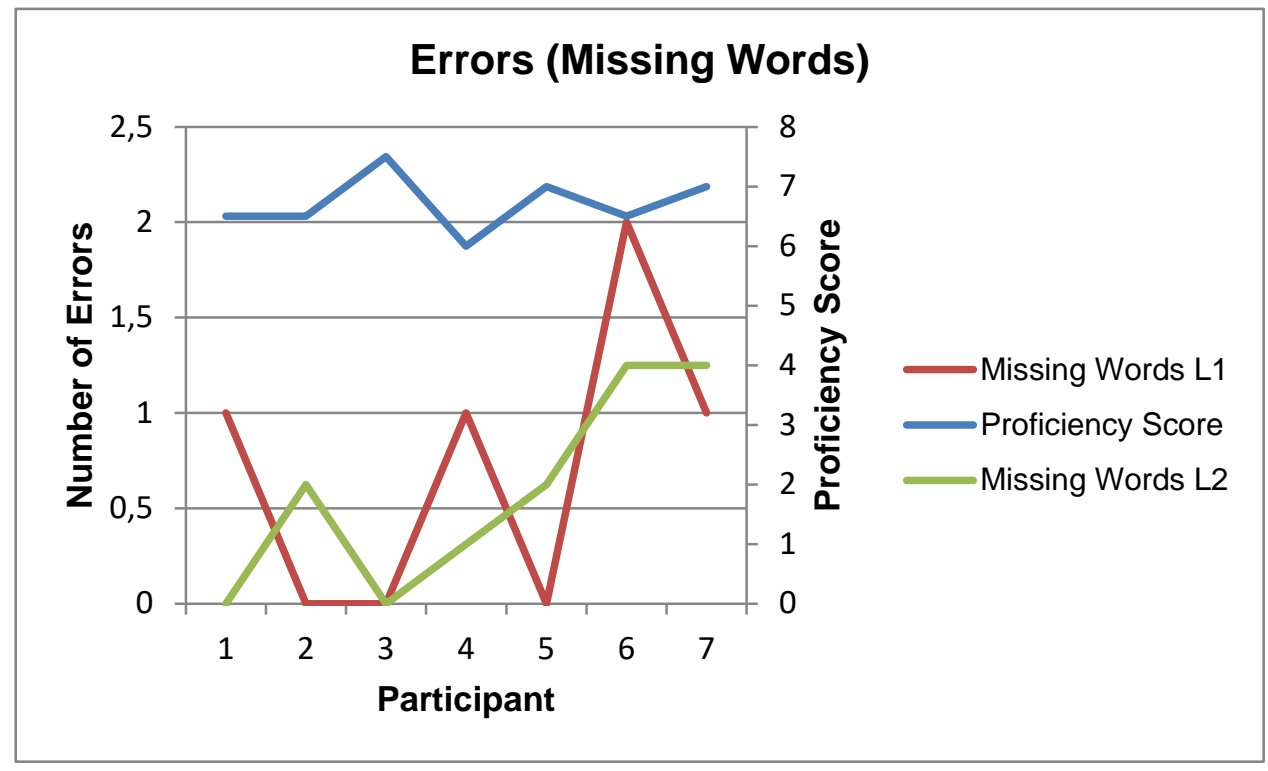

Fig. 3. The Line-chart of Proficiency Score and Errors (Missing Words) when Reading the L1 and L2 Scrambled Texts

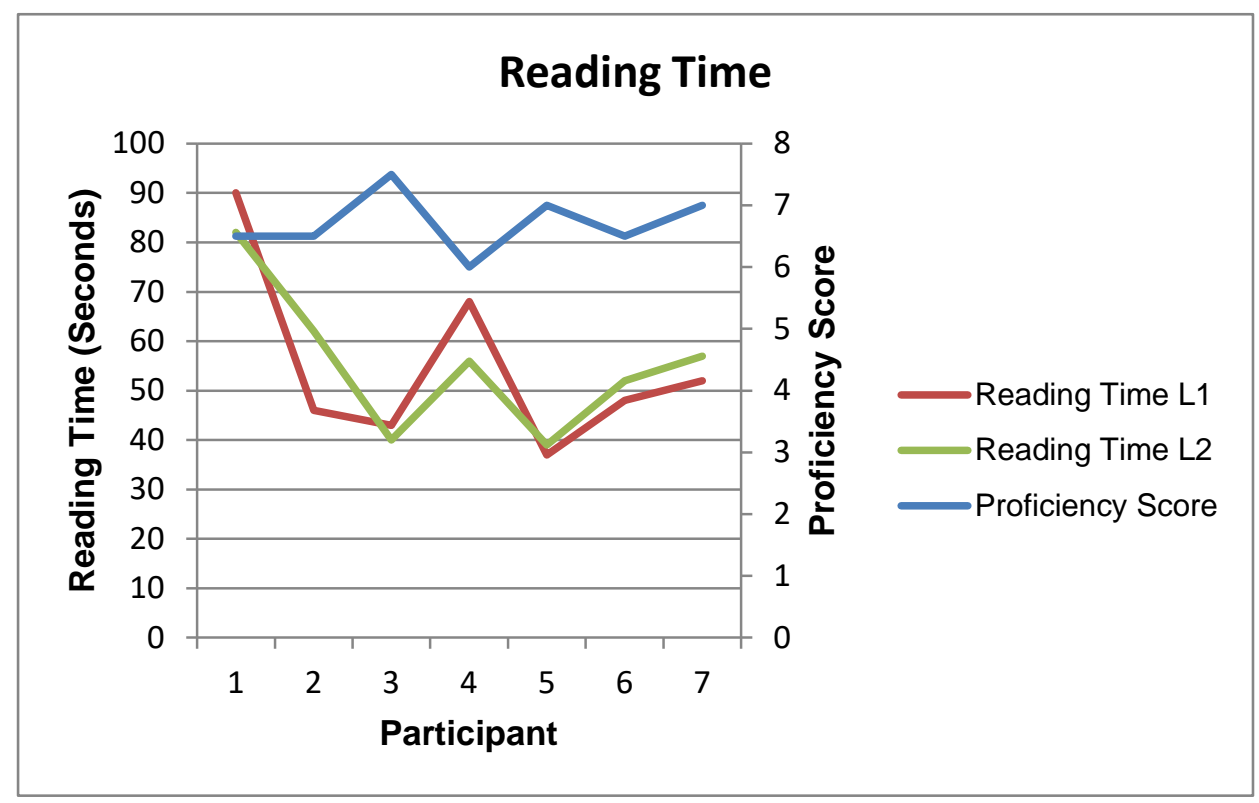

Fig. 4. The Line-chart of Proficiency Score and Time when Reading the L1 and L2 Scrambled Texts

The correlations among proficiency level, numbers of errors, and reading time are illustrated in the line charts. Figure 5 shows no specific pattern occurring among the variables. The numbers of errors in L1 (represented by the red line) and L2 (represented by the green line) scrambled texts are randomly dispersed, regardless of the participants' proficiency level.

Meanwhile, Figure 6 presents the participants' reading time in the form of a line chart for ease of comparison between the variables. The chart shows that the reading time needed by the participants for the L1 and L2 scrambled texts varied. 
The supportive or competitive relationship between the variables was not apparent.

\section{Discussion}

The present study explores how learners with different proficiency levels access their L1 and L2 lexical knowledge. The number of missing words and reading time were also employed to help investigate learners' performance.

From the results of data analysis using the paired-samples t-test and correlation analysis (Pearson), it can be inferred that, on average, participants at any proficiency level produced fewer errors in reading the $\mathrm{L} 1$ scrambled text compared to the L2 scrambled text. Concerning the reading time of each text, participants read the L1 scrambled text faster than the L2 scrambled text. However, there are two particular words (one in L1 and another one in L2) that most of the participants were unable to pronounce accurately. These isolated words are used to identify the gap caused by the different levels of proficiency.

In regard to the correlation of the measured variable, the study was able to highlight three key points. First of all, in answering the first research question, it can be concluded that the way participants access their lexical items for L1 and L2 is quite similar. Although Jiang and Forster claimed that L2 words are stored in a different memory system from L1 words, ${ }^{14}$ (see also Kavitha \& Kannan, ${ }^{15}$

\footnotetext{
${ }^{14}$ Jiang and Forster hypothesized that L1 words are stored in the semantic memory while L2 words are stored in the episodic memory, see more Nan Jiang and Kenneth I. Forster, "Cross-Language Priming Asymmetries in Lexical Decision and Episodic
}

and Meara $^{16}$ ) however, when they were asked to read the $\mathrm{L} 2$ scrambled text, all participants directly recalled any words relating to the scrambled words. Apparently, the participants did not need to access their $L 1$ lexical items in reading the L2 scrambled text, suggesting that the participants' proficiency levels were sufficient (medium level).

In answering the second research question, results show that participants with higher proficiency levels access their L1 and L2 lexical items faster and more easily than those with lower proficiency levels. It can be suggested that this is due to higher language and linguistic skills, particularly in terms of reading skills, vocabulary knowledge, and syntax. This is in line with a study by Zolkapli and Salehuddin. ${ }^{17}$ They argued that proficiency level plays an important role, especially when learners have to activate words from their mental lexicon. Boddaert, Cornut, and Casalis also found that as proficiency level increases, words from two lexicons ( $L 1$ and L2) are progressively integrated. $^{18}$ Kastenbaum et al. also

Recognition," Journal of Memory and Language 44, no. 1 (2001): 35-51, https://doi.org/10.1006/jmla.2000.2737.

15 Sundarachariar Kannan and Kavitha.V, "A Comprehensive Overview of Bilingual Mental Lexicon and Vocabulary Learning: A Psycholinguistic Approach in Language Pedagogy," IJELLS 4, no. 1 (2015): 121-25.

16 Paul Meara, Connected Words: Word Associations and Second Language Vocabulary Acquisition (Amsterdam: John Benjamin Publishing, 2009).

17 Md Zolkapli and Salehuddin, "Lexical Access Patterns of Second Language Speakers of English."

18 G. Boddaert, C. Cornut, and S. Casalis, "Integration of Newly Learned L2 Words into the 
agreed that proficiency, specifically the amount of exposure, contributes to lexical access. $^{19}$

Finally, although the participants with higher proficiency levels generally outperform participants with lower proficiency, it is apparent that the higher the proficiency level, the more complicated their lexical access will be. For example, P5 and P7 are equally proficient, but both still produced errors. Meanwhile, although P4 was the least proficient, they were only short of two words and read both L1 and L2 scrambled texts relatively faster. It is in line with Vögelin's statement that "as the level of language proficiency increases, the degree of lexical sophistication increases as well."20

Several studies have explained a lexical access pattern of second language speakers (Duñabeitia \& Molinaro; ${ }^{21}$ and Field $^{22}$ ), and other researchers (Crosleyy,

Mental Lexicon Is Modulated by Vocabulary Learning Method," Acta Psychologica 212 (2021): 1-11, https://doi.org/10.1016/j.actpsy.2020.103220.

19 Jessica G. Kastenbaum et al., "The Influence of Proficiency and Language Combination on Bilingual Lexical Access," Bilingualism: Language and Cognition 22, no. 2 (2019): 300-330, https://doi.org/10.1017/S1366728918000366.

20 Cristina Vögelin et al., "The Influence of Lexical Features on Teacher Judgements of ESL Argumentative," Assessing Writing 39 (2019): 50 63, https://doi.org/10.1016/j.asw.2018.12.003.

21 Jon Andoni Duñabeitia and Nicola Molinaro, "The Wide-Open Doors to Lexical Access," Frontiers in Psychology 4 (2013): 1-2, https://doi.org/10.3389/fpsyg.2013.00471.

22 J. Field, "Lexical Storage and Lexical Access," in Psycholinguistics: A Resource Book for Students (New York: Routledge 11 New Fetter Lane, 2013), 15-17.
Salsbury, \& McNamara; ${ }^{23}$ Crossley, Kyle, Allen, Guo, \& McNamara; ${ }^{24}$ and $\mathrm{Yu}^{25}$ ) also have found links between language proficiency and lexical diversity. Therefore, the present study contributes to this narrative.

One of the limitations of this study is that it only investigated a small number of participants $(n=7)$. The range of proficiency level indicated by the participants' IELTS scores (or their equivalence) was also not very large, from 6.5 to 7.5. This might affect the overall results of the statistical analyses. Future studies might benefit more from investigating a larger sample size with a wide range of proficiency levels. The degree of exposure to L2, gender, age, and other individual differences should also be taken into consideration.

\section{Conclusion}

Accessing lexical items in L1 and L2 may differ from one person to another and take several related factors into account. Proficiency level, which is an important factor in the study of L2 development, apparently affects the lexical access on L1 and L2. However, this does not necessarily indicate that people with high

\footnotetext{
${ }^{23}$ Scott A. Crossley, Tom Salsbury, and Danielle S. Mcnamara, "Assessing Lexical Proficiency Using Analytic Ratings: A Case for Collocation Accuracy," Applied Linguistics 36, no. 5 (2015): 570-90, https://doi.org/10.1093/applin/amt056.

${ }^{24}$ Scott A. Crossley et al., "Linguistic Microfeatures to Predict L2 Writing Proficiency: A Case Study in Automated Writing Evaluation," The Journal of Writing Assessment 7, no. 1 (2014): 1-34.

${ }^{25}$ Guoxing $\mathrm{Yu}$, "Lexical Diversity in Writing and Speaking Task Performances," Applied Linguistics 31, no. 2 (2010): 236-59, https://doi.org/10.1093/applin/amp024.
} 
proficiency levels will access their lexical items faster and more easily. Another contributing factor to be considered is the individual's language attitudes towards L1 and L2. Notwithstanding the above results, further studies are needed to provide more insight into the correlation between proficiency level and lexical access in L1 and L2.

\section{References}

Boddaert, G., C. Cornut, and S. Casalis. "Integration of Newly Learned L2 Words into the Mental Lexicon is Modulated by Vocabulary Learning Method." Acta Psychologica 212 (2021): 1-11. https://doi.org/10.1016/j.actpsy.2020 .103220.

Bot, Kees De, Wander Lowie, and Marjolyn Verspoor. Second Language Acquisition: An Advanced Resource Book. Routledge: Psychology Press, 2005.

Crossley, Scott A., Kristopher Kyle, Laura K. Allen, Liang Guo, and Danielle S. McNamara. "Linguistic Microfeatures to Predict L2 Writing Proficiency: A Case Study in Automated Writing Evaluation." The Journal of Writing Assessment 7, no. 1 (2014): 1-34.

Crossley, Scott A., Tom Salsbury, and Danielle S. Mcnamara. "Assessing Lexical Proficiency Using Analytic Ratings: A Case for Collocation Accuracy." Applied Linguistics 36, no. 5 (2015): 570-90. https://doi.org/10.1093/applin/amt056.

Dixon, Peter, and Ernst Z. Rothkopf. "Word Repetition, Lexical Access, and the Process of Searching Words and Sentences." Journal of Verbal Learning and Verbal Behavior 18, no. 5 (1979): 629-44. https://doi.org/10.1016/S00225371(79)90354-2.
Duñabeitia, Jon Andoni, and Nicola Molinaro. "The Wide-Open Doors to Lexical Access." Frontiers in Psychology 4 (2013): 1-2. https://doi.org/10.3389/fpsyg.2013.0 0471.

Field, J. "Lexical Storage and Lexical Access." In Psycholinguistics: A Resource Book for Students, 15-17. New York: Routledge 11 New Fetter Lane, 2013.

Grosjean, François. "Studying Bilinguals: Methodological and Conceptual Issues." Bilingualism: Language and Cognition 1, no. 2 (1998): 131-49. https://doi.org/10.1017/S136672899 800025X.

Jiang, Nan, and Kenneth I. Forster. "Cross-Language Priming Asymmetries in Lexical Decision and Episodic Recognition." Journal of Memory and Language 44, no. 1 (2001): 32-51. https://doi.org/10.1006/jmla.2000.27 37.

Kannan, Sundarachariar and Kavitha.V. "A Comprehensive Overview of Bilingual Mental Lexicon and Vocabulary Learning: A Psycholinguistic Approach in Language Pedagogy." IJELLS 4, no. 1 (2015): 121-25.

Kastenbaum, Jessica G., Lisa M. Bedore, Elizabeth D. Peña, Li Sheng, Ilknur Mavis, Rajani Sebastian-Vaytadden, Grama Rangamani, Sofia VallilaRohter, and Swathi Kiran. "The Influence of Proficiency and Language Combination on Bilingual Lexical Access." Bilingualism: Language and Cognition 22, no. 2 (2019): 300-330. https://doi.org/10.1017/S136672891 8000366.

Kroll, J. F., and A. Dijkstra. "The Bilingual Lexicon." In Handbook of Applied Linguistics, by R. Kaplan, 301-21. Oxford: Oxford University Press, 2002. 
Lengyel, Zsolt, and Judit Navracsics. Second Language Lexical Processes. Second Language Lexical Processes. Clevedon: Multilingual Matters, 2007. https://www.degruyter.com/document /doi/10.21832/9781853599682/html.

Maera, Paul. Connected Words: Word Associations and Second Language Vocabulary Acquisition. Amsterdam: John Benjamin Publishing, 2009.

McClelland, James L., and David E. Rumelhart. "An Interactive Activation Model of Context Effects in Letter Perception: I. An Account of Basic Findings." Psychological Review 88, no. 5 (1981): 375-407. https://doi.org/10.1037/0033295X.88.5.375.

Md Zolkapli, Rasyiqah Batrisya, and Khazriyati Salehuddin. "Lexical Access Patterns of Second Language Speakers of English." Gema Online Journal of Language Studies 19, no. 4 (2019): 48-65. https://doi.org/10.17576/gema-20191904-03.

Persici, Valentina, Marilyn Vihman, Roberto Burro, and Marinella Majorano. "Lexical Access and Competition in Bilingual Children: The Role of Proficiency and the Lexical Similarity of the Two Languages." Journal of Experimental Child Psychology 179 (2019): 103-25. https://doi.org/10.1016/j.jecp.2018.1 0.002 .

Singleton, David. Exploring the Second Language Mental Lexicon. Cambridge: Cambridge University Press, 1999.

Vögelin, Cristina, Thorben Jansen, Stefan D. Keller, Nils Machts, and Jens Möller. "The Influence of Lexical Features on Teacher Judgements of ESL Argumentative." Assessing Writing 39 (2019): 50-63. https://doi.org/10.1016/j.asw.2018.1 2.003.
Weinreich, Uriel. Languages in Contact: Findings and Problems. Berlin: Walter de Gruyter, 2010.

$\mathrm{Yu}$, Guoxing. "Lexical Diversity in Writing and Speaking Task Performances." Applied Linguistics 31, no. 2 (2010): 236-59.

https://doi.org/10.1093/applin/amp0 24. 


\section{Appendix}

Research Instrument

\section{Two scrambled texts in L1 (Indonesian) and L2 (English)}

I awlyas snag taht nresruy rymhe wtih my mtoehr borefe ginog to selep. It was fun for me sncie my mtoehr otefn tlod me so mnay mgacial srtieos bhined it. One of the mtoenms taht I msot rbemeemerd was wehn she gvae me a ctasyrl blal at one ngiht and siad, 'Tihs ctasyrl blal is vrey uqiune. If you hvae a good hraet, yuor wsih wlil be ganretd by God.' I gvae a vrey hgue atnetoitn to her bsauece it sduoned azinamg for me, as cdiherln had teihr own wlrod.

I always sang that nursery rhyme with my mother before going to sleep. It was fun for me since my mother often told me so many magical stories behind it. One of the moments that I most remembered was when she gave me a crystal ball at one night and said, 'This crystal-ball is very unique. If you have a good heart, your wish will be granted by God.' I gave a very huge attention to her because it sounded amazing for me, as children had their own world.

Syaa slelau mikayenanyn lgau aank itu bsaerma ibu syaa selebum pgeri tdiur. Bgai syaa itu mnaenyengkan kranea ibu syaa sinerg mricentakaen kadepa syaa bitegu byaank citera aijab di byikalna. Saalh stau moemn ynag pinalg syaa igant aldaah ktikea biaelu memerbi syaa suaebh bloa kstaril pdaa stuau maalm dan bkeatra, 'Bloa kstaril ini sganat uink. Jkia kmau mpuyeamni htai ynag biak, knangeiin kmau aakn dbilkakaun oelh Tuhan.' Syaa merematikphan apa ynag biaelu kakatan kranea itu tdegernar mubkjenakan bgai syaa, lanykaya aank-aank ynag mpuyaemni diuna mekera sidenri.

Saya selalu menyanyikan lagu anak itu bersama ibu saya sebelum pergi tidur. Bagi saya itu menyenangkan karena ibu saya sering menceritakan kepada saya begitu banyak cerita ajaib di baliknya. Salah satu momen yang paling saya ingat adalah ketika beliau memberi saya sebuah bola kristal pada suatu malam dan berkata, 'Bola kristal ini sangat unik. Jika kamu mempunyai hati yang baik, keinginan kamu akan dikabulkan oleh Tuhan.' Saya memperhatikan apa yang beliau katakan karena itu terdengar menakjubkan bagi saya, layaknya anak-anak yang mempunyai dunia mereka sendiri. 